\title{
Goat kid slaughter value and muscle quality after dietary supplementation with an alfalfa protein-xanthophyll concentrate
}

\author{
Anna Szymanowska ${ }^{1}$, Anna Miduch ${ }^{1}$, Tomasz Maria Gruszecki ${ }^{1}$, Monika Greguła-Kania ${ }^{1}$, and \\ Eugeniusz Ryszard Grela ${ }^{2}$ \\ ${ }^{1}$ Institute of Animal Breeding and Biodiversity Conservation, \\ University of Life Sciences, 20-950 Lublin, Akademicka 13, Poland \\ ${ }^{2}$ Institute of Animal Nutrition and Bromatology, University of Life Sciences, \\ 20-950 Lublin, Akademicka 13, Poland \\ Correspondence to: Monika Greguła-Kania (gregulakania@gmail.com)
}

Received: 24 March 2017 - Revised: 10 September 2017 - Accepted: 12 October 2017 - Published: 23 November 2017

\begin{abstract}
The objective of this study was to determine the effect on goat kids of supplementation with proteinxanthophyll concentrate (PX) obtained from alfalfa (Medicago sativa). Assessments were made on carcass dressing percentage and the lipid profiles of muscle tissue. When the animals reached 30 days old (the start of the fattening period), they were allocated to two feeding groups: a control group (K), which received a standard concentrate diet, and an experimental group (D), which was fed a modified control diet where $3 \%$ of the soybean meal was replaced with an alfalfa protein-xanthophyll preparation (PX). For the rest of the study the kids had ad libitum access to dam milk, hay and their respective diets. After 90 days of rearing (from the end of the fattening period up to when the kids were approximately 120 days of age), five (male) kids were randomly selected from each group and slaughtered. Overall, PX supplementation in goat kids does not affect any parameters of fattening, such as slaughter weight, daily weight gains or dressing percentage. However, beneficial effects of feeding with PX concentrate were found in a higher loin percentage and improved tissue composition resulting from lower fat tissue content. Moreover the PX dietary supplement improved the chemical composition of the muscle tissue by increasing the content of protein and unsaturated fatty acids. Taken together, our results suggest that supplementing the fattening diet for goat kids with the PX preparation did not affect the quantitative parameters of fattening but had a positive influence on the quality of carcass composition.
\end{abstract}

\section{Introduction}

In the production of food animals, raw meat quality largely depends on the type and quality of feed as well as supplements added to the feed (Thacker, 2013; Grela and Kowlaczuk, 2007). As antibiotic growth promoters were banned from European Union states on 1 January 2006, subsequent studies have focused on natural and safe additives that could be incorporated into animal diets. Particular attention has been paid to plant-derived preparations containing phytochemicals with nutraceutical properties. One such preparation is a protein-xanthophyll concentrate (PX) obtained from alfalfa (Medicago sativa). This product contains
55-60\% general protein with a rich amino acid composition, high content of polyunsaturated fatty acids and xanthophyllous natural yellow dye (1200-2200 $\mathrm{mg} \mathrm{d}^{-3}$ ) (Grela and Pietrzak, 2014). The concentrate has a high chlorophyll content, easily absorbable iron and other important mineral components indispensable for the proper functioning of physiological processes.

PX is an important supplement because it can be included in both human and animal diets (Bresson et al., 2009; Gaweł, 2012). The preparation constitutes an excellent source of protein, vitamins and other nutrients and promotes optimal health and growth of juvenile animals (Grela and Pietrzak, 2014). Indeed, studies have indicated PX is effective in hu- 
man nutrition (Vyas et al., 2010) as well as the feed of poultry (Grela et al., 2014), pigs (Ueda and Ohshima, 1989), rabbits (Asgary et al., 2008), cattle, sheep and even fish (Rechulicz et al., 2014). Overall, the studies showed PX concentrate from alfalfa improves animal performance as well as the quality of products from the animals (such as meat, milk and eggs) and modifies blood metabolite profiles in the animals.

Alfalfa PX can be used as a dietary supplement in both monogastric and ruminant animal feed, which is another advantage of this preparation for the production of safe food. Positive results from a variety of farm animal species (Davys et al., 2011; Grela et al., 2008; Krauze and Grela, 2010) suggest that PX may have utility as a supplement in the diet of goat kids. There would be benefits from replacing $3 \%$ of soybean meal with PX concentrate in the diet of goat kids. The replacement should be considered in terms of both its quantitative and its qualitative aspects. The quantitative aspects include production parameters (such as animal growth and dressing yields), while qualitative aspects cover tissue composition and nutritive value expressed by the fatty acid profiles in the muscle tissue.

The nutritive value of goat kid meat for humans is well established and recognized. Furthermore, kids are easily acclimated to a wide range of habitats, which makes it easy to increase the size of the herd and produce valuable animal food products for human consumption (Anaeto et al., 2010).

The objective of this study was to determine the effect of supplementation with PX on goat kids. Assessments were made on carcass dressing percentage and the lipid profiles of muscle tissue.

\section{Materials and methods}

The study was conducted in duplicate (in 2012 and 2013) and included 82 Saanen goat kids. A total of 38 (19 control and 19 experimental group) kids were studied in 2012, and 44 (22 control and 22 experimental group) kids were studied in 2013. During both studies the sex ratios (of young male bucklings and young female doelings) were similar in the groups. Ethical approval was obtained from the local ethics commission (consent form number 8/2013). The animals were maintained under uniform environmental and feeding conditions with constant zootechnical and veterinary supervision.

When the kids reached 30 days old (the start of the fattening period), they were allocated to two feeding groups: a control group (K), which received a standard concentrate diet, and an experimental group (D), which was fed a modified control diet where $3 \%$ of the soybean meal was replaced with an alfalfa protein-xanthophyll preparation (Table 1). For the rest of the study, the kids had ad libitum access to dam milk, hay and their respective diets.

The kid body weights were recorded at birth and at the beginning and end of the fattening period. These measurements were used to calculate the daily weight gain during the
Table 1. Ingredient composition (by percent of dry weight), nutritional value of the analyzed diets and forage intake in the groups of animals.

\begin{tabular}{lrr}
\hline Item & $\begin{array}{c}\text { Group } \\
\text { Control } \\
n=41\end{array}$ & $\begin{array}{r}\text { Experimental } \\
n=41\end{array}$ \\
\hline Oats & 38 & 38 \\
Wheat & 15 & 15 \\
Barley & 15 & 15 \\
Wheat bran & 15 & 15 \\
Dry beet pulp & 8 & 8 \\
Soybean meal & 8 & 5 \\
Protein-xanthophyll concentrate & - & 3 \\
Mineral-vitamin additive & 1 & 1 \\
1 kg mixture contained the following: & & \\
crude protein $\left(\mathrm{g} \mathrm{kg}^{-1}\right)$ & 113 & 131 \\
net energy $\left(\mathrm{MJ} \mathrm{kg}^{-1}\right)^{\mathrm{b}}$ & 6.74 & 5.93 \\
forage intake $\left(\mathrm{kg} \mathrm{kg}^{-1}\right.$ of body weight) & 2.2 & 1.9 \\
\hline a Composition of mine & &
\end{tabular}

${ }^{\mathrm{a}}$ Composition of mineral-vitamin mixture $\mathrm{kg}^{-1}$ : vitamin $\mathrm{A}-600000 \mathrm{IU}$; vitamin $\mathrm{D}-$ $50000 \mathrm{IU}$; vitamin $\mathrm{E}-600 \mathrm{mg}$; vitamin $\mathrm{B}_{1}-25 \mathrm{mg}$; vitamin $\mathrm{B}_{2}-20 \mathrm{mg}$; vitamin $\mathrm{B}_{6}-$

$17 \mathrm{mg}$; vitamin $\mathrm{B}_{12}-250 \mu \mathrm{g}$; nicotinic acid $-500 \mathrm{mg}$; folic acid $-5 \mathrm{mg}$; biotin $-10 \mathrm{mg}$; calcium - $210 \mathrm{~g}$; phosphorus $-40 \mathrm{~g}$; magnesium $-30 \mathrm{~g}$; sodium $-80 \mathrm{~g}$; zinc $-4 \mathrm{~g}$; manganese $-2 \mathrm{~g}$; iodine $-50 \mathrm{mg}$; selenium $-130 \mathrm{mg}$; cobalt $-30 \mathrm{mg}$.

b Net energy ( $\mathrm{MJ} \mathrm{kg}^{-1}$ of the feed) calculated according to the formula given in Tables of composition and nutritional value of feed materials (Sauvant, 2002).

fattening season. After 90 days of rearing (from the end of the fattening period up to when the kids were approximately 120 days of age), 5 kids (only male) were randomly selected from each group and slaughtered (20 in total). After $24 \mathrm{~h}$ cooling at $4{ }^{\circ} \mathrm{C}$, the carcasses were divided into primary cuts followed by detailed leg dissection according to the procedure outlined by Krupiński et al. (2009). The longest muscle (musculus longissimus) was sampled for laboratory analyses of the muscle tissue. The basic chemical composition was determined by analyzing the contents of dry matter, crude protein, ether extract and ash according to AOAC methods (Latimer, 2012).

The longissimus musculus samples were analyzed for cholesterol and fatty acid contents. The separation and quantification of fatty acid methyl esters were carried out using a gas chromatograph (Varian 450-GC). The chromatograph operating conditions for fatty acid separation were as follows: the capillary column was a CP-WAX 52CB $(0.25 \mathrm{~mm} \times 60 \mathrm{~m}$ length $)$; the gas carrier was helium with a flow rate of $1.4 \mathrm{~mL} \mathrm{~min}^{-1}$; the column temperature was initially $120^{\circ} \mathrm{C}$, gradually increased by $2{ }^{\circ} \mathrm{C} \mathrm{min}^{-1}$ up to $210^{\circ} \mathrm{C}$; the determination time was $127 \mathrm{~min}$; the feeder temperature was $160^{\circ} \mathrm{C}$; the detector temperature was $160^{\circ} \mathrm{C}$; and the other gases were hydrogen and oxygen. The cholesterol contents of the organs and tissues were measured using the colorimetric method described by Rhee et al. (1982).

All the results were analyzed statistically using Harvey's least square method (1987). The statistical analysis included the linear model

$y_{i j k}=\mu+G_{i}+R_{j}+(\mathrm{GR})_{i j}+e_{i j k}$, 
Table 2. The body weights and daily gains of the goat kids.

\begin{tabular}{llll}
\hline Specification & & $\begin{array}{l}\text { Group } \\
\text { Control } \\
n=41\end{array}$ & Experimental \\
& & & $n=41$ \\
\hline Initial body & LSM & 12.0 & 12.2 \\
weight (kg) & SE & 0.2 & 0.1 \\
Body weight after & LSM & 25.7 & 26.5 \\
fattening (kg) & SE & 1.3 & 1.1 \\
$\begin{array}{l}\text { Daily weight gain } \\
\text { during fattening }\end{array}$ & LSM & 152 & 158 \\
period (g) & SE & 7 & 9 \\
\hline
\end{tabular}

where $y_{i j k}$ is the level of the studied trait, $\mu$ is the arithmetic mean for the population, $G_{i}$ is the effect $(i)$ of a group $(i=1$ or 2$), R_{j}$ is the effect $(j)$ of the research year $(j=1$ or 2$)$, $(\mathrm{GR})_{i j}$ is the effect of the interaction group with the sampling year and $e_{i j k}$ is the random error.

The statistical analyses were performed using SAS (SAS v.9.1.3., 2003). Significant differences between the means were determined using Duncan's multiple range test at both 0.05 and 0.01 significance levels. The results are presented as the means of least squares for each trait (LSM) and standard error (SE) considering only the effect of a group.

\section{Results}

The effect of the research year and group interaction (research year $\times$ group) did not affect any of the outcome parameters. Therefore, the results from both research years have been combined and are presented as averages.

At the onset of the fattening period the kids' body weight in both groups was similar at around $12 \mathrm{~kg}$ (Table 2). After 90 days of fattening, there was a higher body weight in the kids fed the diet supplemented with $3 \%$ alfalfa PX compared to the control group ( 26.5 and $25.7 \mathrm{~kg}$, respectively), but it was not statistically significant. An important parameter of kid growth is daily weight gain. Throughout the time when the groups were fed the analyzed diets (the fattening period), the daily gains in the experimental group were higher by around $4 \%$ compared with their peers in the control group, but this was not statistically significant.

The results obtained at slaughter showed that the cold carcass weight and, consequently, the dressing yield were higher in the experimental group in comparison to the control group by approximately 5 and $2 \%$. Data illustrating the percentage of each cut, kidneys and perirenal fat in a carcass are summarized in Table 3.

The experimental group of young male goat kids fed a diet including the PX additive yielded higher percentages $(p<$ 0.05 ) of both loin (by $8 \%$ ) and kidney fat (by $20 \%$ ) compared to the control group. The percent yields of the other cuts in the carcass were similar in both groups. In addition to the primal cuts, a detailed dissection of the leg was performed
Table 3. Percentage of primal cuts, kidneys and perirenal fat obtained from the carcasses (\%).

\begin{tabular}{|c|c|c|c|}
\hline \multirow[t]{2}{*}{ Item } & & \multirow{2}{*}{$\begin{array}{l}\text { Group } \\
\text { Control } \\
n=10\end{array}$} & \multirow{2}{*}{$\begin{array}{l}\text { Experimental } \\
n=10\end{array}$} \\
\hline & & & \\
\hline \multirow[t]{2}{*}{ Neck } & LSM & 7.73 & 7.63 \\
\hline & SE & 0.27 & 0.19 \\
\hline \multirow[t]{2}{*}{ Forequarter } & LSM & 8.98 & 9.01 \\
\hline & SE & 0.54 & 0.30 \\
\hline \multirow[t]{2}{*}{ Shoulder } & LSM & 16.93 & 16.24 \\
\hline & SE & 0.94 & 0.43 \\
\hline \multirow[t]{2}{*}{ Flank with breastbone } & LSM & 17.36 & 17.33 \\
\hline & SE & 0.43 & 0.44 \\
\hline \multirow[t]{2}{*}{ Foreshank } & LSM & 4.74 & 4.60 \\
\hline & SE & 0.06 & 0.14 \\
\hline \multirow[t]{2}{*}{ Hind shank } & LSM & 5.67 & 6.00 \\
\hline & SE & 0.05 & 0.34 \\
\hline \multirow[t]{2}{*}{ Rack } & LSM & 5.91 & 5.72 \\
\hline & SE & 0.18 & 0.14 \\
\hline \multirow[t]{2}{*}{ Loin } & LSM & $6.50^{*}$ & $7.04^{*}$ \\
\hline & SE & 0.17 & 0.24 \\
\hline \multirow[t]{2}{*}{ Leg } & LSM & 23.57 & 23.13 \\
\hline & SE & 0.35 & 0.38 \\
\hline \multirow[t]{2}{*}{ Valuable cuts } & LSM & 35.98 & 35.89 \\
\hline & SE & 0.44 & 0.37 \\
\hline \multirow[t]{2}{*}{ Kidney } & LSM & 0.83 & 0.86 \\
\hline & SE & 0.03 & 0.07 \\
\hline \multirow[t]{2}{*}{ Kidney fat } & LSM & $1.78^{*}$ & $2.14^{*}$ \\
\hline & SE & 0.25 & 0.42 \\
\hline \multirow[t]{2}{*}{ Cold carcass weight $(\mathrm{kg})$} & LSM & 12.3 & 12.9 \\
\hline & SE & 1.0 & 0.5 \\
\hline \multirow[t]{2}{*}{ Cold dressing yield (\%) } & LSM & 47.8 & 48.8 \\
\hline & SE & 1.05 & 0.8 \\
\hline
\end{tabular}

${ }^{*} p \leq 0.05$.

Table 4. Percent tissue composition in the goat legs (\%).

\begin{tabular}{llll}
\hline Item & & $\begin{array}{l}\text { Group } \\
\text { Control } \\
n=10\end{array}$ & Experimental \\
& & & $n=10$ \\
\hline \multirow{2}{*}{ Meat } & LSM & 70.0 & 70.1 \\
& SE & 0.7 & 1.3 \\
Fat & LSM & $7.6^{*}$ & $6.1^{*}$ \\
& SE & 0.8 & 1.0 \\
Bones & LSM & 22.4 & 23.8 \\
& SE & 0.7 & 1.2 \\
\hline
\end{tabular}

${ }^{*} p \leq 0.05$

to analyze tissue composition, and the results are summarized in Table 4.

The data show that both muscle and bone tissue contents in the kids from both groups were at very similar levels. However, the experimental-group animals were found to have a lower leg fat content by around $20 \%(p<0.05)$. 
Table 5. Chemical composition of goat kid muscle tissue by percent (\%).

\begin{tabular}{llll}
\hline Item & & $\begin{array}{l}\text { Group } \\
\text { Control } \\
n=10\end{array}$ & Experimental \\
& & & $n=10$ \\
\hline \multirow{2}{*}{ Dry matter } & LSM & 25.5 & 25.4 \\
& SE & 0.2 & 0.21 \\
Protein & LSM & $21.6^{*}$ & $22.3^{*}$ \\
& SE & 0.2 & 0.11 \\
\multirow{3}{*}{ Ash } & LSM & $2.02^{* *}$ & $1.54^{* *}$ \\
& SE & 0.11 & 0.09 \\
& LSM & 1.31 & 1.32 \\
& SE & 0.02 & 0.03 \\
\hline
\end{tabular}

${ }^{*} p \leq 0.05 ;{ }^{* *} p \leq 0.01$.

Within the muscle tissue itself the analysis of composition (Table 5) revealed that the kids receiving the PX concentrate diet had higher $(p<0.05)$ protein levels $(22.3 \%)$ compared with the control group $(21.6 \%)$. As for fat, a difference was observed in the adipose content, which was $23.7 \%$ lower $(p<0.01)$ in the kids from the experimental group compared to the control group. The contents of dry matter and ash were similar among the groups.

Further analyses of the muscle tissue were performed to assess fatty acid composition. Eleven different fatty acids containing 10-20 carbon atoms were identified and are presented in Table 6. Of the 11 fatty acids we identified, cis-9octadecenoic (oleic, $\mathrm{C}_{18: 1}$ ) acid was the most common, hexadecanoic (palmitic, $\mathrm{C}_{16: 0}$ ) acid was the second most common and octadecanoic (stearic, $\mathrm{C}_{18: 0}$ ) was the third most common. There were detected lower amounts of 7 out of the 11 identified fatty acids in the experimental group. In particular, capric $\left(\mathrm{C}_{10: 0}\right)$ and lauric $\left(\mathrm{C}_{12: 0}\right)$ acid contents were lower by 50 and $28 \%$, respectively, in the experimental group.

On the other hand, several unsaturated fatty acids were found to be higher in the experimental group, including linoleic $\left(\mathrm{C}_{18: 2}\right)$, gamma-linolenic $\left(\mathrm{C}_{18: 3 n 6}\right)$ and alphalinolenic $\left(\mathrm{C}_{18: 3 \mathrm{n} 3}\right)$ acid. Comparing the levels of fatty acids by group (Table 7) showed that the unsaturated fatty acid content was $5 \%$ higher in the experimental group, while the saturated fat content was lower $(p<0.01)$. The ratio of unsaturated to saturated acids was higher $(p<0.05)$ in the experimental group as was the ratio of monounsaturated fats to polyunsaturated fats. Furthermore, the goat kids fed PX in their diet had a reduced $(p<0.05)$ cholesterol content in their muscle, by $10.1 \%$, compared to the control.

\section{Discussion}

The production parameters (body weight gain, dressing percentage) assessed in the present study were not affected by the diet. We conclude the PX dietary additive did not affect
Table 6. Percentage of fatty acids identified in the lipid fraction of muscle tissue (\%).

\begin{tabular}{|c|c|c|c|}
\hline \multirow[t]{2}{*}{ Item } & & \multirow{2}{*}{$\begin{array}{l}\text { Group } \\
\text { Control } \\
n=10\end{array}$} & \multirow{2}{*}{$\begin{array}{l}\text { Experimental } \\
n=10\end{array}$} \\
\hline & & & \\
\hline \multirow[t]{2}{*}{$\mathrm{C}_{10: 0}$} & LSM & $0.25^{* *}$ & $0.12^{* *}$ \\
\hline & SE & 0.02 & 0.01 \\
\hline \multirow[t]{2}{*}{$\mathrm{C}_{12: 0}$} & LSM & $0.39^{*}$ & $0.28^{*}$ \\
\hline & $\mathrm{SE}$ & 0.07 & 0.06 \\
\hline \multirow[t]{2}{*}{$\mathrm{C}_{16: 0}$} & LSM & 21.99 & 21.13 \\
\hline & SE & 0.28 & 0.44 \\
\hline \multirow[t]{2}{*}{$\mathrm{C}_{18: 0}$} & LSM & 14,97 & 13.47 \\
\hline & SE & 0.21 & 0.28 \\
\hline \multirow[t]{2}{*}{$\mathrm{C}_{15: 1}$} & LSM & 0.12 & 0.23 \\
\hline & SE & 0.01 & 0.06 \\
\hline \multirow{2}{*}{$\mathrm{C}_{18: 1}$} & LSM & 46.22 & 47.36 \\
\hline & SE & 0.83 & 0.61 \\
\hline \multirow[t]{2}{*}{$\mathrm{C}_{20: 1}$} & LSM & 0.15 & 0.18 \\
\hline & SE & 0.01 & 0.01 \\
\hline \multirow{2}{*}{$\mathrm{C}_{18: 2 \mathrm{n} 6}$} & LSM & $3.80^{*}$ & $4.92^{*}$ \\
\hline & SE & 0.23 & 0.16 \\
\hline \multirow[t]{2}{*}{$\mathrm{C}_{18: 3 \mathrm{n} 6}$} & LSM & $0.07^{* *}$ & $0.13^{* *}$ \\
\hline & SE & 0.01 & 0.01 \\
\hline \multirow[t]{2}{*}{$C_{18: 3 n 3}$} & LSM & $0.31^{* *}$ & $0.45^{* *}$ \\
\hline & SE & 0.02 & 0.04 \\
\hline \multirow[t]{2}{*}{$\mathrm{C}_{20: 2}$} & LSM & 0.24 & 0.28 \\
\hline & SE & 0.06 & 0.06 \\
\hline \multirow[t]{2}{*}{$\mathrm{C}_{20: 3 \mathrm{n} 6}$} & LSM & 0.16 & 0.19 \\
\hline & SE & 0.02 & 0.04 \\
\hline
\end{tabular}

${ }^{*} p \leq 0.05 ;{ }^{* *} p \leq 0.01$.

the production parameters under study. From an economic point of view, it is important that the values observed in the present study were close to those obtained under similar fattening protocols for goat kids reported by other authors, such as Naderer (1999) and Ringdorfer (2001). A lack of effect of alfalfa in the diet of goat kids on their growth and slaughter performance is also corroborated in the literature (Philips et al., 2002). In that study, the authors enriched a diet used to fatten goat kids with dried alfalfa at an amount comparable to the level of PX concentrate used in the present study and likewise found no influence on weight gain. Further studies should investigate whether the production parameters could be improved in other goat breeds and crossbreeds and also during the finishing stage. We did find positive differences due to diet in the primal cuts of the carcasses. It was found that the PX alfalfa supplement improved the loin content in the carcasses, the cut recognized as the most desired for culinary purposes. Its percentage was higher by $8.3 \%$, and this suggests that the PX additive may have major implications for qualitative parameters and warrants further research. The present study also found the PX preparation contributes to increased fat tissue, mainly perirenal fat. However, as these 
Table 7. Percent fatty acid and cholesterol profiles in the lipid fraction of the goat kid muscle (\%).

\begin{tabular}{|c|c|c|c|c|}
\hline \multicolumn{2}{|l|}{ Item } & \multirow{2}{*}{$\begin{array}{l}\text { Control } \\
n=10\end{array}$} & \multicolumn{2}{|l|}{ Group } \\
\hline & & & $n=10$ & \\
\hline \multirow[t]{8}{*}{ Fatty acids } & saturated (SFA) & LSM & $43.07 * *$ & $40.32 * *$ \\
\hline & & SE & 0.51 & 0.33 \\
\hline & unsaturated (UFA) & LSM & $56.92 * *$ & $59.67 * *$ \\
\hline & & SE & 0.51 & 0.33 \\
\hline & monounsaturated (MUFA) & LSM & 51.82 & 53.10 \\
\hline & & SE & 0.86 & 0.94 \\
\hline & polyunsaturated (PUFA) & LSM & $6.03 *$ & $7.75 *$ \\
\hline & & SE & 0.74 & 0.78 \\
\hline \multirow{2}{*}{\multicolumn{2}{|c|}{ MUFA/PUFA }} & LSM & $0.11 *$ & $0.14^{*}$ \\
\hline & & SE & 0.01 & 0.01 \\
\hline \multirow{2}{*}{\multicolumn{2}{|c|}{ UFA/SFA }} & LSM & $1.32 *$ & $1.48 *$ \\
\hline & & SE & 0.02 & 0.01 \\
\hline \multirow{2}{*}{\multicolumn{2}{|c|}{ Cholesterol, mg/100 g }} & LSM & $71.4 *$ & $64.2 *$ \\
\hline & & SE & 1.9 & 1.7 \\
\hline
\end{tabular}

${ }^{*} p \leq 0.05 ; * * 0.01$

fat depots are normally removed after slaughter, the culinary or nutritional quality of the goat muscle tissue is not diminished.

Indeed, tissue composition is one of the essential components in assessments of carcass quality and slaughter value of goat kids. In this study, to reduce time and labor costs, carcass tissue composition was analyzed based on a detailed dissection of the leg. Such an analysis is considered reliable both from the authors' personal experience as well as according to literature data (Tahir et al., 1994). The present findings on tissue composition in the control group are consistent with those reported by other authors (Mioc, 2001; Ringdorfer, 2001) on standard kid carcasses. Importantly, we did observe a difference between the feeding groups in the adipose tissue content in the leg. The fat content was reduced by approximately $24 \%$ without any reduction in muscle tissue in the goats fed the $3 \%$ PX concentrate. This shift in tissue composition considerably improves the nutritional and culinary qualities of the meat.

If the healthiest food products promote positive human physiological functions and reduce disease risks, it is not surprising that much criticism has arisen regarding products of animal origin (such as meat and milk) because of their high fat content and their fatty acid profiles. It has been reported that for optimal health, the human body requires $30 \%$ of total energy intake to be derived from fat and specifically that one-third should come from saturated fats, more than onethird from monounsaturated fats and less than one-third from polyunsaturated fatty acids. The content of each fatty acid in a living organism is dependent on a number of factors, diet and dietary supplements playing pivotal roles among them (Webb and O`Neal, 2008). In the current study, the analy- sis of each fatty acid group showed that the PX supplement had a positive and significant effect on kid muscle lipid fractions by increasing unsaturated fatty acid levels and at the same time decreasing saturated fatty acid levels. Beneficial changes were also observed in polyunsaturated fatty acid contents and the ratios between the different types of fats.

Aside from fatty acids, cholesterol content is also associated with food quality, and the present research has indicated a significant relationship between PX dietary inclusion and cholesterol content in goat kid muscles. Specifically, cholesterol content was approximately $10 \%$ lower in the experimental group supplemented with PX. This is a novel finding, as we are aware of no literature addressing the subject of the influence of the PX concentrate on the content of fatty acids or cholesterol in goat kid meat. Several studies have concluded a link between diet and fat profiles in ruminants, such as those by Banskalieva et al. (2000), Juarez et al. (2008), Kesava-Rao et al. (2003), Niedziółka et al. (2006) and Sheridan et al. (2003).

\section{Conclusions}

Overall, PX supplementation in goat kids does not affect any parameters of fattening such as slaughter weight, daily weight gains or dressing percentage. However, beneficial effects of feeding PX concentrate were found in higher loin percentage and improved tissue composition due to lower fat tissue content. Moreover, the PX dietary supplement improved chemical composition of the muscle tissue by increasing the content of protein and unsaturated fatty acids. Taken together, our results suggest that supplementing the fattening diet for goat kids with the PX preparation did not affect 
quantitative parameters of fattening but had a positive influence on the quality of carcass composition.

Data availability. The original data are available upon request from the corresponding author.

Author contributions. AS conceived and designed the study, performed the research and wrote the paper and assumed primary responsibility for the final content; AM performed the research, analyzed the data, wrote the paper; TMG supported the design of the study, analyzed data and critically revised the paper; MG-K performed the research, critically revised the paper and conducted statistical data analysis; EG supported the design of the study, analyzed data and critically revised the paper.

All the authors have read and approved the final manuscript.

Competing interests. The authors declare that they have no conflict of interest.

Edited by: Steffen Maak

Reviewed by: Pavel Novak and three anonymous referees

\section{References}

Anaeto, M., Adeyeye, J. A., Chioma, G. O., Olarinmoye, A. O., and Tayo, G. O.: Goat products: meeting the challenges of human health and nutrition, Agric. Biol. J. N. Am., 1, 1231-1236, 2010.

Asgary, S., Moshtaghian, J., Hosseini, M., and Siadat, H.: Effects of alfalfa on lipoproteins and fatty streak formation in hypercholesterolemic rabbits, Pak. J. Pharm. Sci., 21, 460-464, 2008.

Banskalieva, V., Sahlu, T., and Goetsch, A. L.: Fatty acid composition of goat muscles and fat depots; a review, Small Ruminant Res., 37, 255-268, 2000.

Bresson, J. L., Flynn, A., Heinonen, M., Hulshof, K., Korhonen, H., Lagiou, P., Løvik, M., Marchelli, R., Martin, A., Moseley, B., Przyrembel, H., Salminen, S., Strain, J. J., Strobel, S., Tetens, I., Van Den Berg, H., Van Loveren, H., and Verhagen, H.: Opinion on the safety of "Alfalfa protein concentrate" as food, The European Food Safety Authority Journal, 997, 1-19, 2009.

Davys, M. N. G., Richardier, F.-C., Kennedy, D., de Mathan, O., Collin, S. M., Subtil, J., Bertin, E., and Davys, M. J.: Leaf concentrate and other benefits of leaf fractionation, in: Combating Micronutrients Deficiencies: Food-based Approaches, edited by: Thompson, B. and Amoroso, L., Rome, FAO, 338-365, 2011.

Gaweł, E.: Chemical composition of Lucerne leaf extract (EFL) and its applications as a phytobiotic in human nutrition, Acta Sci. Pol., Technol. Aliment., 11, 303-310, 2012.

Grela, E. R. and Kowalczuk, E.: Herbs in animal feeding, Herba Pol., 53, 361-366, 2007.

Grela, E. R. and Pietrzak, K.: Production technology, chemical composition and use of alfalfa protein-xanthophyll concentrate as dietary supplement, Journal of Food Processing and Technology., 5, 373-377, 2014.

Grela, E. R., Semeniuk, W., and Florek, M.: Effects of proteinxanthophyll (PX) concentrate of alfalfa additive to crude protein- reduced diets on nitrogen excretion, growth performance and meat quality of pigs, Journal Central European Agriculture, 8, 669-676. 2008.

Grela, E. R., Ognik, K., Czech, A., and Matras, J.: Quality assessment of eggs from laying hens fed a mixture with lucerne protein concentrate, J. Anim. Feed. Sci., 23, 236-243, 2014.

Harvey, W. R.: Mixed model least - squares and maximum likelihood computer program, Ohio State University, Ohio, USA, 1987.

Juarez, M., Horcada, A., Alcalde, M. J., Valera, M., Mullen, A. M., and Molina, A.: Estimation of factors influencing fatty acid profiles in light lambs, Meat. Sci., 79, 203-210, 2008.

Kesava-Rao, V., Kowale, B. N., and Verma, A. K.: Effect of feeding water washed neem (Azadirachta indica) seed Kornel cake on the quality, lipid profile and fatty acid composition of goat meat, Small Ruminant Res., 47, 213-219, 2003.

Krauze, M. and Grela, E. R.: The influence of the proteinxanthophyll (PX) alfalfa concentrate used as an additive in turkey diet on performance and some blood indices, Arch. Geflugelkd., 74, 226-232, 2010.

Krupiński, J., Borys, B., Kieć, W., Knapik, J., Korman, K., Osikowski, M., Pompa-Roborzyński, M., and Rzepecki, R.: Assessment of the utility lambs meat against the requirements and methods used in the European Union, Institute of Animal Production, Cracow, 2009.

Latimer, G. W.: AOAC: Official methods of analysis of AOAC International, Gaithersburg, Maryland, USA, 2012.

Mioc, B., Pavic, V., and Ivankovic, A.: Some carcass traits and chemical composition of different muscle groups in Alpine and Saanen breed kids, Czech J. Anim. Sci., 46, 83-87, 2001.

Naderer, J.: Hohes Schlachtkörpergewicht und gute Fleischqualität bei Lämmern der Burenziege, Der Ziegenzüchter, 15, 3-7,1999.

Niedziółka, R. and Pieniak-Lendzion, K.: Chemical composition of meat (M. adductor) and fatty acids in intramuscular fat of goat kids and ram lambs, Slovak, J. Anim. Sci., 39, 197-200, 2006.

Phillips, W. A., Reuter, R. R., Brown, M. A., Fitch, J. Q., Rao, S. R., and Mayux, H.: Growth and performance of lambs fed a finishing diet containing either Alfalfa or Kenaf as the roughage source, Small Ruminant Res., 46, 74-79, 2002.

Rechulicz, J., Ognik, K., and Grela, E. R.: The effect of adding protein-xanthophylls concentrate (PX) from alfalfa (Medicago sativa) on growth parameters and redox profile in muscles of carp, Cyprinus carpio (L.), Turk. J. Fish. Aquat. Sc., 14, 3, 697703, 2014.

Rhee, K. S., Dutson, T. R., Smith, G. C., Hostetler, R. L., and Reiser, R.: Cholesterol content of raw and cooked beef longissimus muscles with different degrees of marbling, J. Food. Sci., 47, 716-719, 1982.

Ringdorfer, F.: Einfluss von Genotyp, Geschlecht und Endgewicht auf die Schlachtleistung von Ziegenkitzen, Arch. Tierzucht, 44, 385-390, 2001.

Sauvant, D., Perez, J.-M., and Tran, G.: Tables de composition et de valeur nutritive des matières premières destinées aux animauxd'élevage. Porcs, volailles, bovins, ovins, caprins, lapins, chevaux, poisons, INRA Editions, Paris, 2002.

Sheridan, R., Hoffman, L. C., and Ferreira, A. V.: Meat quality of Boer kids and mutton Merino lambs 1 commercial yields and chemical composition, Anim. Sci., 76, 63-71, 2003. 
Thacker, P. A.: Alternatives to antibiotics as growth promoters for use in swine production: a review, J. Anim. Sci. Biotechno., 4, 35-46, 2013.

Tahir, M. A., Al-Jassim, A. F., and Abdulla, A. H. H.: Influence of live weight and castration on distribution of meat, fat and bone in the carcass of goats, Small Ruminant Res., 1, 355-368, 1994.

Ueda, H. and Ohshima, M.: Nutritive value of alfalfa leaf protein concentrate prepared from low saponin variety in chicks and pigs, Japanese Journal of Zootechnical Science, 60, 561-566, 1989.
Webb, E. C. and O'Neill, H. A.: The animal fat paradox and meat quality, Meat. Sci., 80, 28-36, 2008.

Vyas, S., Collin, S. M., Bertin, E., Davys, G. J., and Mathur, B.: Leaf concentrate as an alternative to iron and folic acid supplements for anaemic adolescent girls: a randomised controlled trial in India, Public Health Nutr., 13, 418-423, 2010. 